\title{
El nuevo estado de naturaleza mexicano
}

\section{JOSÉ FABIÁN RUIZ*}

\author{
El libro La formación del sistema político mexicano de Víctor López Villafañe apareció en 1986, \\ pero recientemente volvió a publicarse en una tercera edición actualizada. Se retoman \\ los acontecimientos previos a la etapa de 1988, a la vez que se examinan los hechos políticos \\ y sociales más relevantes de la historia de México desde ese periodo hasta la actualidad.
}

Siglo Xxi Editores acaba de publicar una edición actualizada de La formación del sistema político mexicano, libro de Víctor López Villafañe que fue publicado por primera vez en 1986, y del que existen dos ediciones y cinco reimpresiones. Este hecho es elocuente: se trata de un texto que goza de gran aceptación por parte del público en el ámbito académico desde hace ya treinta años.

En cuanto a la nueva edición, cuyo subtítulo es De la hegemonía posrevolucionaria a la hegemonía neoliberal, retoma el hilo conductor del texto original en el punto donde acaban las ediciones anteriores, la etapa previa a la elección de 1988, auténtico hito en la vida política nacional. Ello le otorga máximo interés a la edición, ya que revisa y analiza los acontecimientos más destacados de nuestra historia reciente hasta la actualidad. Al finalizar, el lector conserva la sensación de haber examinado una versión del Leviatán, pero a la inversa: si bien es cierto que el orden posrevolucionario fue autoritario, en tanto que asentó su hegemonía en una fuerte represión política y social frente a cualquier proyecto disidente, lo que siguió a su crisis a partir de 1988 fue el surgimiento de un nuevo estado de naturaleza, cuyas consecuencias son esbozadas por López Villafañe de forma contundente. Dicho derrumbe encierra un tremendo riesgo, aunque el autor aboga por la creación de un orden democrático, inclusivo, representativo y progresista, es sólo una de las posibilidades que se abren frente al estado de naturaleza y, a menudo, ni siquiera es la más popular. Aquí reside uno de los puntos más provocadores de la nueva edición con miras al futuro.

Releer el trabajo de López Villafañe enfrenta al lector con un análisis articulado de nuestra historia contemporánea, partiendo del supuesto de que la Revolución mexicana fue orientada por el sector de la burguesía nacional que se oponía a los terratenientes y al grupo vinculado con los capitales foráneos, en el ámbito interno. En el plano internacional el enemigo a confrontar eran los intereses imperialistas. Para llevar a cabo ese cometido, la Revolución contó con el apoyo de campesinos y obreros. Tal coalición de intereses
*Docente investigador del Instituto de Investigaciones Sociales, Universidad Autónoma de Nuevo León. 
para responder de forma efectiva por los daños causados ante el terremoto de 1985 en la Ciudad de México, y alcanzó su máxima elocuencia con la «caída del sistema», acaecida en las elecciones presidenciales de 1988 .

A partir de ese momento inicia la nueva edición del texto, en la que el autor destaca diversas cuestiones, entre ellas el reacomodo producido en la clase política y empresarial mexicana en la década de 1990 (con la dificultad adicional y creciente de tener que distinguirlas). Las corrientes conservadoras se coaligaron con la tecnocracia financiera, depositaria del poder político dentro del Partido Revolucionario Institucional (PRI) desde los 1980. Se conformó entonces un nuevo grupo de interés al que se sumaron viejos sectores del antiguo régimen (incluyendo a su oposición «leal», el panismo) y grupos empresariales nacionales ligados a las industrias tradicionales y monopólicas. Así se generó un entramado variopinto en el que con la mezcla de un segmento del empresariado y el viejo partido junto a otras fuerzas políticas, unidos por el afán de obtener beneficios directos. Dicho grupo logró consolidarse y perdurar en el tiempo, tal como quedó manifestado en el «Pacto por México», a principios del presente sexenio. Es una nueva elite extractiva, poco democrática y escasamente competitiva desde el punto de vista económico, cuyo desempeño se aprecia con claridad en la actualidad. ${ }^{3}$

Esto permitió el triunfo de Vicente Fox, representante de los grupos empresariales asociados con el conservadurismo reformista, aunque «sin proyecto político real», ${ }^{4}$ al que siguió el sexenio de Felipe Calderón. A pesar de las diferencias que mediaron entre ambos presidentes, sus gestiones coincidieron en impedir la consolidación de un proyecto político y social alternativo. En ello no hay diferencias entre la nueva coalición y el modelo posrevolucionario. De ese modo persiste la divisa del viejo sistema que sostiene:

${ }^{3}$ Ibid., pp. 225-236.

${ }^{4}$ Ibid., p. 225.
Es negativo para la clase gobernante aceptar los reclamos populares y como consecuencia las instituciones centrales de la democracia, como la participación ciudadana, la transparencia, la solución a los conflictos con apego a derecho, quedando sólo como retórica que sirve a la demagogia gubernamental como argumento de que México vive ya en la democracia. ${ }^{5}$

Como hipótesis, Víctor López Villafañe advierte que no existe entre las elites nacionales el deseo de que la democracia se consolide, por lo que estimulan los peores vicios del sistema que impiden un auténtico cambio político. ${ }^{6} \mathrm{El}$ actual sexenio no es una excepción en la materia: representa un momento de caída e invalidación social incontrastable.

El fresco que pinta el autor es tan complejo y a la vez tan elocuente, que de inmediato evoca con palabras a la mejor tradición del muralismo mexicano. Quien haya tenido la suerte de visitar el Palacio Nacional en la Ciudad de México, recordará el fantástico mural pintado por Diego Rivera, La epopeya del pueblo mexicano, situado en el espacio de la escalera de acceso a la planta superior. En el ala izquierda se encuentra el mural El México de hoy y mañana que cuenta con un diseño de tres planos, como indica Enrique Florescano. ${ }^{7}$ En el espacio inferior destacan las luchas de campesinos y obreros, en huelgas y reclamos para garantizar sus derechos. En el plano superior se impone la figura de Karl Marx: el maestro Rivera creía genuinamente que ese era el futuro deseable para el país e ilustraba así su aspiración política. En el centro, entre ambos planos, se observa a la clase política y empresarial, enmarañada en una tubería a través de la cual

\footnotetext{
${ }^{5}$ Ibid., p. 234.

${ }^{6}$ Ibid., p. 235.

${ }^{7}$ Enrique Florescano, «El relato histórico acuñado por el Estado posrevolucionario», «Historia de las historias de México», suplemento mensual de La Jornada, 10 de noviembre de 2000, http://www.jornada.unam.mx/2001/04/06/historias.html
} 
se drenan los recursos del país. ${ }^{8}$ En ese sentido, López Villafañe pinta con palabras, tan elocuentes y gráficas como las imágenes del maestro Rivera, un mural similar pero actualizado. Desde finales del siglo pasado, elites diversas se coaligaron para imponer un proyecto extractivo y poco democrático, a pesar de la creciente resistencia social que se alza en su contra. El aspecto negativo es que Rivera acabó su mural en 1935 y en varias cuestiones seguimos inmersos en luchas y rezagos similares a 80 años de distancia.

La parte nueva del libro, el capítulo 5, se transforma en un relato elocuente de los problemas del México actual: el dominio de una elite fragmentada, más unida por sus intereses y su escaso apego a los valores democráticos; la consolidación de un amplio abanico de degradación políticas de distinta índole; la falta de Estado de derecho que refuerce y garantice las aspiraciones de la ciudadanía; la convergencia entre la clase extractiva y los medios de comunicación dominantes; el advenimiento del crimen organizado, incluso como nueva fuente de recursos; el avasallamiento de los derechos humanos, especialmente de los sectores populares; el exiguo crecimiento económico; la democracia nominal, de poca calidad, de baja intensidad y de nula ejemplaridad. Todo esto como resultado de un régimen degradado, que convirtió al proyecto de la burguesía en plan político a falta de uno propio.

Sin embargo, al igual que en aquella caja de espantos que Pandora abrió pese a la advertencia divina, López Villafañe abre sobre el final de su análisis una alternativa al futuro: la acción incansable de distintos grupos de la sociedad en la búsqueda de nuevos horizontes:

Los movimientos sociales y la participación ciudadana que ellos han representado han sido am-

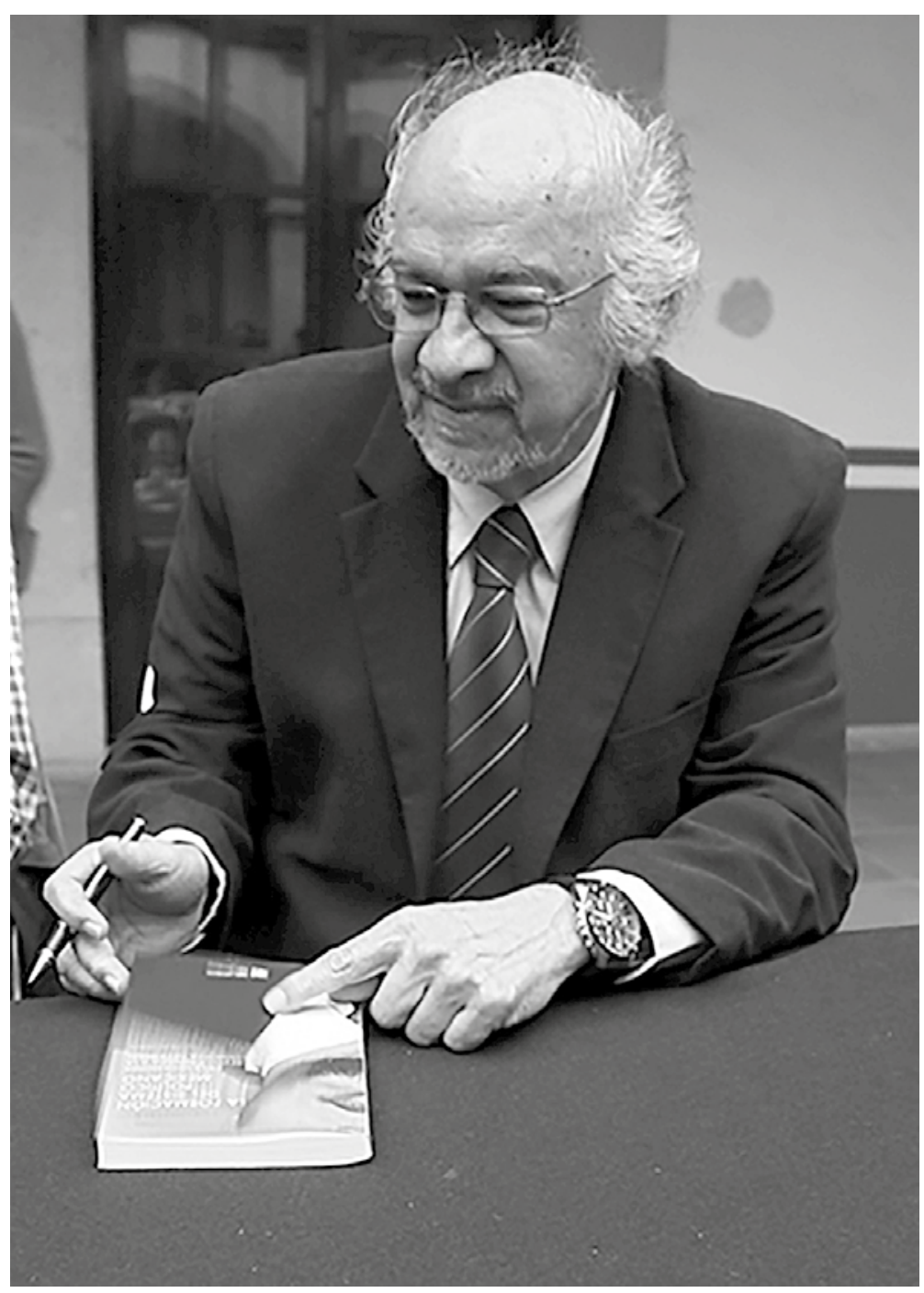

plios, diversos y muy ricos en sus propuestas a lo largo de todas estas décadas. Han sido un ingrediente importante para movilizar al país y evitar mayores trastornos del autoritarismo que bajo nuevas formas se da en el país. ${ }^{9}$

De tal forma, los hechos negativos mencionados en el libro no han desmovilizado, ni desmotivaron a la ciudadanía. Al contrario, actúan como acicate de una sociedad que pelea, que enfrenta a las adversidades y mantiene su capacidad de resistencia. No obstante, una interrogante se impone de inmediato: ¿los diferentes grupos sociales de oposición

\footnotetext{
${ }^{9}$ Víctor López Villafañe, op. cit., p. 234.
}

Víctor López Villafañe durante la presentación del libro en el patio del Museo de Ciencias. ${ }^{8}$ Idem. 
serán capaces de promover, mediante sus acciones, el espacio para el advenimiento de un proyecto político democrático e inclusivo? Más aún, ¿cómo construir un proyecto alternativo que sea capaz de enfrentar a la hegemonía actual y lograr su consolidación a través de medios estrictamente democráticos en un contexto viciado de irregularidades? Son dos de las cuestiones centrales que plantea el texto.

El último siglo de vida política nacional encuentra en Víctor López Villafañe a un analista claro, comprometido e implacable. El libro gene- ra interrogantes, moviliza y cuestiona al lector, de forma directa e inteligente. Nos hallamos ante una obra que explica con facilidad su vigencia editorial y académica. Es posible aseverar, sin temor a exageraciones, que el texto comentado se ha convertido en un clásico de la literatura sobre el sistema político mexicano y, lo que es más importante aún, una obra imprescindible para quien intente comprender esta época, de la que el autor es un testigo y analista de claridad meridiana.

\section{Lectura recomendada}

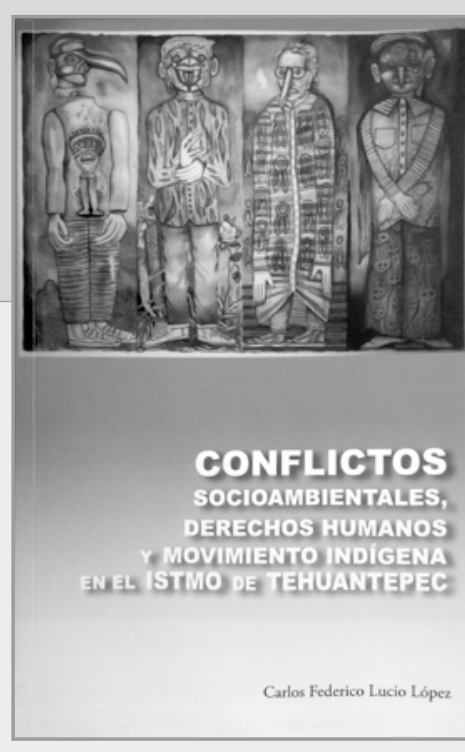

\section{Conflictos socioambientales, derechos humanos y movimiento indígena en el Istmo de Tehuantepec}

Carlos Federico Lucio López

Universidad Autónoma de Zacatecas

Zacatecas, 2016

El libro analiza las luchas indígenas por la defensa de la tierra y el territorio. La intensificación de ciertas dinámicas de desarrollo de carácter extractivo ha desencadenado numerosos focos de conflicto al introducir nuevas formas de despojo de los bienes comunes, que además de amenazar la identidad y la cultura indígena impactan de manera negativa su fuente principal de subsistencia, agravan la condición de pobreza y marginación, y llegan a constituir serias violaciones a los derechos patrimoniales y humanos al representar procesos de desposesión de territorialidades indígenas y campesinas. Se examina también la problemática del despojo territorial en dos estudios de caso localizados en el Istmo de Tehuantepec. En el primero se abordan los efectos del desarrollo en una comunidad del bajo mixe; el segundo pone de relieve la resistencia al megaproyecto eólico impuesto en el macrosistema lagunar huave. 